\title{
Impact of Public Debt, Lending Interest Rate, Public Spending and Money Supply on Private Consumption in South Asian Countries: An Econometric Analysis
}

\author{
MUHAMMAD REEHAN HAMEED \\ Assistant Professor of Economics, Department of Economics, \\ Government College of Science, Wahdat Road, Lahore, Punjab, Pakistan. \\ Email: reehanhameed@yahoo.com \\ Tel: +923456368268 \\ Dr. GHULAM SARWAR \\ Assistant Professor, Faculty of Social Sciences, \\ University of Sargodha, Sargodha, Punjab, Pakistan. \\ Email: sarwar.maqbool@uos.edu.pk \\ Tel: +923336797487
}

\section{Dr. MUHAMMAD ABDULLAH}

Assistant Professor of Economics, Department of Economics, University of Sahiwal, Sahiwal, Punjab, Pakistan.

Email: mabdullah@uosahiwal.edu.pk

Tel: +923007586909

\begin{abstract}
The public debt of South Asian countries has witnessed a continuous increase from the last three decades which has badly affected the household private consumption expenditures. High public debt can lead to steep losses for banks, both domestic and international, undermines the stability of financial systems in both the crisis-hit country and others. This can hit economic growth as well as private consumption. The purpose of this study is to examine the impact of public debt on private consumption in South Asian countries i.e. Bangladesh, Bhutan, India, Maldives, Nepal, Pakistan, and Sri Lanka. Besides public debt, the impact of some other important macroeconomic, fiscal, and monetary variables like lending interest rate, public spending and money supply have also been examined. For this purpose, 31 years of panel data from 1990 to 2020 of South Asian countries have been taken. The study has used a variety of econometric techniques like Robust Least Square Regression, Panel Cointegration, Error Correction Model (ECM), Wald test, and Panel Fully Modified Least Squares (FMOLS) approach to examine the short-run and longrun relationship among the variables. The results of Robust Least Square Regression indicate that public debt discourages private consumption. The lending interest rate also badly affected private consumption. The other variables like public spending and money supply have a favorable impact on private consumption. The results of the Kao Residual Panel Cointegration Test and the Johansen Fisher Panel Cointegration Test indicate that there exists a long run relationship among the variables. The results of the ECM and Wald Test reveal that a long run and short-run causality is running from independent variables to the dependent variable respectively. The study recommends that by using monetary and fiscal policies effectively the private consumption and economic growth can be stimulated in the economy.
\end{abstract}

Keywords: South Asia, Public Debt, Private Consumption, Lending Interest Rate Public Spending, Money Supply, Robust Least Square Regression, ECM, FMOLS, Wald Test. 


\section{Introduction}

The behavior of economic activities in an economy is determined by demand and supply of commodities. Private consumption is an important factor of aggregate expenditures which depends on income and taxes. Along with the increase in income, private consumption also increases while any increase in taxes decreases consumption. Income tax is considered to be the major source of revenue to finance government expenditures. If the government revenues falls short of its expenditures then it plans to borrow from internal or external sources and increases the tax rates. An important question arises in our mind whether the government should reduce the taxes or increase debt and what is their impact on private consumption expenditures? Various economists have given different views to answer the above question. According to the Keynesian view, the government may curtail taxes which indirectly increases fiscal deficits but enhances private consumption due to an increase in disposable income.

On the other hand, Ricardian are of the view that any tax cut which is finance through an increase in debt will bring no change in private consumption because a rationale consumer thinks that the present tax cut will bring an artificial increase in his disposable income which could be bring back from him in future in the form of increased taxes to repay the debt along with its servicing charges. The answer to the question is very much helpful for the policymakers to manage the economy in a better way because private consumption expenditures are the major driver of economic activities in developing countries and negative factors, such as public debt, public spending, and inflation (Kochin, 1974; Kormendi, 1983 and Oseni, 2016). It is evident from Table 1 given below that the public debt of all the South Asian countries is showing an increasing trend from the last three decades.

Table 1: The trend of Public Debt (PD) (US Billion \$)

\begin{tabular}{|lccccccc|}
\hline Year & Bangladesh & Bhutan & India & Maldives & Nepal & Pakistan & Sri Lanka \\
\hline $\mathbf{1 9 9 0}$ & 15.80 & 0.15 & 226.34 & 1.91 & 0.07 & 32.75 & 7.76 \\
$\mathbf{1 9 9 5}$ & 18.59 & 0.12 & 247.77 & 2.91 & 0.19 & 47.31 & 12.40 \\
$\mathbf{2 0 0 0}$ & 24.76 & 0.18 & 340.14 & 3.49 & 0.25 & 59.13 & 15.82 \\
$\mathbf{2 0 0 5}$ & 32.57 & 0.79 & 654.40 & 4.17 & 0.43 & 70.77 & 22.11 \\
$\mathbf{2 0 1 0}$ & 37.24 & 1.06 & 1118.22 & 5.36 & 1.27 & 105.71 & 40.62 \\
$\mathbf{2 0 1 5}$ & 54.04 & 2.04 & 1461.16 & 5.42 & 1.96 & 169.13 & 62.59 \\
$\mathbf{2 0 1 6}$ & 61.33 & 2.62 & 1582.86 & 5.43 & 2.37 & 187.82 & 64.45 \\
$\mathbf{2 0 1 7}$ & 67.68 & 2.73 & 1784.48 & 6.56 & 2.71 & 203.00 & 67.65 \\
$\mathbf{2 0 1 8}$ & 89.50 & 3.08 & 2009.48 & 8.77 & 3.01 & 212.89 & 69.70 \\
$\mathbf{2 0 1 9}$ & 94.56 & 3.38 & 2195.12 & 9.92 & 3.22 & 226.23 & 72.22 \\
$\mathbf{2 0 2 0}$ & 98.45 & 3.65 & 2290.13 & 10.2 & 3.78 & 245.12 & 75.77 \\
\hline
\end{tabular}

Source: International Debt Statistics various databases.

When economic activities slow down, consumers become very careful about spending. In this situation, the government takes various initiatives to flourish economic activities and minimize the budget deficits in the economy. Similarly, an increase in inflation and interest rate decreases the purchasing power and consumption in the economy (Li, Wei \& Xu, 2017; Soon -Siew, Baharumshah \& Mohamad Shariff, 2017).

Private consumption expenditures change due to some positive and negative factors, such as public debt, public spending, and inflation (Kochin, 1974; Kormendi, 1983 and Oseni, 2016). Higher interest rates are thought to affect consumer spending through both substitution and income effects. A higher interest rate lowers consumption through the substitution effect because current consumption becomes expensive relative to savings. Households reduce their spending today in favor of spending tomorrow. Higher interest rates tend to moderate economic growth. 
Higher interest rates increases the cost of borrowing, reduce disposable income, and therefore limit the growth of consumer spending. Higher interest rates tend to reduce inflationary pressure and cause an appreciation in the exchange rate. Rising government spendings are likely to cause aggregate demand (AD) to increase. This can lead to higher growth in the short-term. Higher government spending will also have an impact on the supply-side of the economy-depending on which area of government spendings are increased. By increasing the amount of money supply in the economy, the central bank encourages private consumption. Increasing the money supply also decreases the interest rate, which encourages lending and investment. The increase in consumption and investment leads to higher aggregate demand (AD).

The main objectives of the study are

- To investigate the impact of Public debt on Private Consumption in South Asian Countries.

- To examine the impact of Lending Interest Rate on Private Consumption in South Asian Countries.

- To analyze the effect of Public Spending on Private Consumption in South Asian Countries.

- To investigate the impact of Money Supply on Private Consumption in South Asian Countries.

- $\quad$ To suggest some policy recommendations on the basis of the findings.

\section{Research Questions of the study}

The study is designed to answer the following research question.

- What is the impact of Public Debt on Private Consumption in South Asian Countries?

- What is the impact of Lending Interest Rate on Private Consumption in South Asian Countries?

- What is the effect of Public Spending on Private Consumption in South Asian Countries?

- What is the impact of Money Supply on Private Consumption in South Asian Countries?

\section{Literature Review}

Karras (1994) analyzed the association between private consumption expenditures and public spending. For this purpose 38 years data for a number of selected countries from 1950 until 1987 had been used. The results of the study revealed that private consumption and government spending are complementary where the increase in government spending has the potential to improve marginal private consumption.

Berben and Brosens (2005) examined the relationship between public debt and private consumption in OECD countries. The result of the study revealed that there existed a non-linear relationship between public debt and private consumption. The study further explained that the impact of public debt on consumption depends on the level of debt. The countries whose debt levels were low, public debt did not affect private consumption. In contrast, countries with high debt levels of government debt tend to have a significant negative impact on private consumption. In other words, high debt levels led to the implementation of fiscal policies less effective in stabilizing fluctuations in the business cycles.

Linnemann (2006) investigated the impact of public spending on private consumption. The result of the study revealed that government spending had a positive impact on private spending. He postulated that occurrence of cyclical changes of government, households tend to respond positively to private consumption. The result further indicated that the higher fiscal spending of the government raised consumption and reduced investment in the economy.

Reinhart and Rogoff (2010) found out association among growing public indebtedness, growth performance, and inflation. They used the data of 44 developed countries. The results indicated that after a specific level of debt to GDP ratio ( $90 \%$ and above), public indebtedness had affected growth negatively in 
developed countries. Moreover, in emerging market economies, the thresh hold level of external debt was $60 \%$ of GDP. But the relationship between public indebtedness and inflation had different effects on emerging and advanced economies. In advanced economies, no systematic link had been found between growing debt and inflation. But in emerging economies, public debt had a positive association with inflation.

Shahzad and Javid (2015) analyzed the effect of public indebtedness on productivity and investment in developing Asian nations. For this purpose, 23 years of data from 1984-2007 had been used. Panel fixed effect model and GMM econometric techniques were applied on five years average data and annual data set respectively. The results indicated that debt had negatively associated with investment and growth. The budget deficit also had a negative effect on investment and productivity. The study results demonstrated that due to the crowding effect, the debt had a negative impact on investment. The crowding-out effect reveled that higher debt level compelled the government either to increase taxes or acquired loans from banks which discouraged private investment in the economy. The study suggested that comprehensive debt reduction strategies would be adopted to reduce the deficit for increasing private sector investment and productivity in the economy.

Coccia (2017) examined the relationship between public debt and budget deficits in EMU countries. The results of the study indicated that along with an increase in budget deficits public debt increases and as a result the tax rate also increases to bring the budget deficit down in EMU countries. The study concluded that increased public debt created debt obligations and interest payments. The rational agents expected that the government would increase tax rate in future to pay the debt obligations which decreased the return from the capital, their income and net wealth.

Pegkas (2018) examined the association among public indebtedness, economic growth, and some other macroeconomic variables in Greece. The study had used 46 years of data from 1970 to 2016. The result indicated that both public debt and population growth negatively correlated with economic growth. The other macroeconomic variables like trade openness, private sector investment, and public expenditures stimulated economic growth. The study concluded that the biggest challenge for the policymakers in Greece was to achieve sustainable growth along with the mounting level of indebtedness.

\section{The Econometric Model}

The general form of model can be written as:

$$
P R V C_{\text {it }}=\beta_{0}++\beta_{1} P D_{\text {it }}+\beta_{2} L I R_{\text {it }}+\beta_{3} P U B S_{\text {it }}+\beta_{4} M S_{\text {it }}+\mu_{\text {it }}
$$

Where

$$
\begin{aligned}
& \alpha_{0}=\text { Intercept } \\
& i=\text { Cross section dimensions. } \\
& t=\text { Time-series dimensions. } \\
& \mathrm{PRVC}_{\mathrm{it}}=\text { Private Consumption } \\
& \mathrm{PD}_{\text {it }}=\text { Public Debt } \\
& \mathrm{LIR}_{\mathrm{it}}=\text { Lending Interest Rate } \\
& \mathrm{PUBS}_{\text {it }}=\text { Public Spending } \\
& \mathrm{MS}_{\mathrm{it}}=\text { Money Supply }
\end{aligned}
$$




\section{Data Source and Estimation Techniques}

To examine the impact of public debt, lending interest rate, public spending, and money supply on private consumption 31 years of panel data of South Asian countries i.e. Bangladesh, Bhutan, India, Maldives, Nepal, Pakistan, and Sri Lanka from 1990 to 2020 have been taken. Data has been collected from World Development Indicators (WDI), International Monetary Fund (IMF), and International Debt Statistics various database. The study uses the following econometric techniques for estimation of data.

1. Panel Unit Root Test

2. Robust Least Squares Regression

3. Kao Residual Panel Cointegration Test

4. Johansen Fisher Panel Cointegration

5. Vector Error Correction Model (VECM)

6. Wald Test

7. Panel Fully Modified Least Squares (FMOLS)

\section{Results Discussion and Analysis: Robust Least Squares Regression Results}

The results of robust least regression given in Table 2 indicate that public debt has negatively and significantly associated with private consumption (PRVC) in South Asian Countries. A one unit increase in public debt leads to a decrease in private consumption by 0.13 units. Mounting public debt (PD) increases taxes and lowers the wage rate. All will lead to decrease disposable household incomes, depress savings, reduce aggregate consumption, and ultimately let down economic growth. The rising level of public debt implies higher future taxes on households which decreases their disposable income and consumption. Moreover, due to the increase risk of default, the banks also give them less loans which further reduces households consumption level (Peersman \& Pozzi, 2004).

Table 2: Robust Least Squares Regression Results Dependent Variable: Private Consumption (PRVC)

\begin{tabular}{|ccccc|}
\hline Variable & Coefficient & Std. Error & t-Statistic & Prob. \\
\hline PD & -0.134631 & 0.035602 & $-3.781581 * * *$ & 0.0002 \\
LIR & -0.845579 & 0.105424 & $-8.020769 * * *$ & 0.0000 \\
PUBS & 5.434013 & 0.170887 & $31.79880 * * *$ & 0.0000 \\
MS & 0.536234 & 0.013307 & $40.29827 * * *$ & 0.0000 \\
C & 29.48987 & 2.477453 & $11.90330 * * *$ & 0.0000 \\
\hline *** Significant at 1\% & & & &
\end{tabular}

It means that fiscal expansion partly crowds out household's private consumption (Berben, \& Brosens, 2007). It leads to conclude that fiscal policy is less effective in stabilizing business cycle fluctuations due to the rising trend of public debt in these countries. Lending interest rate also has a negative association with private consumption. One percent increase in interest rate decreases private consumption by 0.84 units. When the interest rate paid by the banks on the deposits increases it triggers households to save more to earn more profits on the deposits in the form of interest rate which shrinks consumption (Musibau et al. 2017).Public spending (PUBS) has a significant and positive relation with private consumption (PRVC). The positive relationship between public spending and private consumption has been supported by (Fatas $\&$ Mihove, 2001 and Castro \& Cos, 2006). The increase in public spending leads to an increase in the level of income, output, and employment in the country, which further stimulates households aggregate consumption (Keynes, 1936). Money supply (MS) also has a significant and positive relationship with private consumption. Increase supply of money in the country raises the level of income which results in enhancing the level of aggregate demand and consumption. 


\section{Panel Unit Root Test Results}

To check the stationary of the variables verity of panel unit root tests have been applied to a given set of data, e.g. Levin, Lin \& Chu Unit Root Test (2002), I'm, Pesaran and Shin Unit Root Test (2003), ADF Fisher Unit Root Test and Phillips - Perron Fisher Panel Unit Root Test (1988). The null hypothesis is that the series is stationary and the alternate hypothesis is that the variables are not stationary. A series is stationary if it has zero mean and constant variance. This study uses all above-mentioned methods. The panel unit root results of Table 3 accept the null hypothesis that series are stationary. The alternate hypothesis that series are stationary is rejected. From the results, it concluded that all the variables are stationary at order 1(1).

Table 3: Panel Unit Root Test Results

\begin{tabular}{|cccccccccc|}
\hline Variables & \multicolumn{3}{c}{ ADF - Fisher Chi-square } & \multicolumn{3}{c|}{ Levin, Lin \& Chu Unit Root Test } \\
& \multicolumn{3}{c}{ PP - Fisher Chi-square } & \multicolumn{3}{c|}{ I'm, Pesaran \& Shin Unit Root Test } \\
\cline { 2 - 10 } & \multicolumn{3}{c}{ I(0) } & \multicolumn{2}{c}{ I(1) } & \multicolumn{3}{c|}{ I(0) } \\
PRVC & Intercept & Intercept & Intercept & Intercept & Intercept & Intercept & Intercept & Intercept \\
& & \& Trend & & \& Trend & & \& Trend & & \& Trend \\
& 0.00922 & 0.40928 & 11.4332 & $23.5449^{* *}$ & 8.50620 & 4.14012 & -0.08804 & $-2.8567^{* *}$ \\
& $(1.000)$ & $(0.9999)$ & $(0.1783)$ & $(0.0027)$ & $(1.0000)$ & $(1.0000)$ & $(0.4649)$ & $(0.0021)$ \\
& 0.00837 & 0.37931 & $22.5862^{* *}$ & $34.2056^{* *}$ & 9.11937 & 6.03884 & -0.37420 & $-3.0105^{* *}$ \\
PD & $(1.000)$ & $(1.0000)$ & $(0.0039)$ & $(0.0000)$ & $(1.0000)$ & 1.0000 & $(0.3541)$ & $(0.0013)$ \\
& 0.00019 & 0.15142 & 4.53452 & $13.4912^{* *}$ & 7.85014 & 2.94298 & 1.76111 & 1.71408 \\
& $(1.0000)$ & $(1.0000)$ & $(0.8060)$ & $(0.0960)$ & $(1.0000)$ & 0.9984 & $(0.9699)$ & $(0.9567)$ \\
& 1.10000 & 0.11174 & $15.9507 * *$ & $30.9975^{* *}$ & 9.62712 & 7.20875 & 1.44316 & 0.29867 \\
LIR & $(1.0000)$ & $(1.0000)$ & $(0.0431)$ & $(0.0001)$ & $(1.0000)$ & 1.0000 & $(0.9255)$ & $(0.3826)$ \\
& 3.75897 & 7.47135 & $15.8249^{* *}$ & 8.51969 & 1.94350 & 1.14315 & -0.22156 & -1.21190 \\
& $(0.8782)$ & $(0.4867)$ & $(0.0450)$ & $(0.3844)$ & $(0.9740)$ & $(0.8735)$ & $(0.4123)$ & $(0.1128)$ \\
& 4.13054 & 10.7280 & $35.1494^{* *}$ & $28.7383^{* *}$ & 1.72438 & 1.29281 & -0.78041 & -0.00238 \\
PUBS & $(0.8452)$ & $(0.2176)$ & $(0.0000)$ & $(0.0004)$ & $(0.9577)$ & $(0.9020)$ & $(0.2176)$ & $(0.4991)$ \\
& 0.08702 & 1.89919 & 11.7589 & 13.2564 & 8.53553 & 5.68990 & 1.55175 & -0.17279 \\
& $(1.0000)$ & $(0.9839)$ & $(0.1623)$ & $(0.1033)$ & $(1.0000)$ & $(1.0000)$ & $(0.9396)$ & $(0.4314)$ \\
& 0.07327 & 2.03050 & $30.2795^{* *}$ & $34.4748^{* *}$ & 8.36056 & 5.79254 & 0.28032 & -0.75014 \\
MS & $(1.0000)$ & $(0.9801)$ & $(0.0002)$ & $(0.0000)$ & $(1.0000)$ & $(1.0000)$ & $(0.6104)$ & $(0.2266)$ \\
& 0.11032 & 1.42211 & 12.7651 & $16.6802^{* *}$ & 5.08713 & 2.22721 & $1.57988^{* *}$ & $-3.3402^{* *}$ \\
& $(1.0000)$ & $(0.9939)$ & $(0.1202)$ & $(0.0336)$ & $(1.0000)$ & $(0.9870)$ & $(0.0571)$ & $(0.0004)$ \\
& 0.04937 & 1.40932 & $23.2422^{* *}$ & $24.4321^{* *}$ & 6.42117 & 3.83921 & -1.06793 & $-1.9510^{* *}$ \\
& $(1.0000)$ & $(0.9941)$ & $(0.0031)$ & $(0.0019)$ & $(1.0000)$ & $(0.9999)$ & $(0.1428)$ & $(0.0255)$ \\
\hline
\end{tabular}

Values in Parentheses are p-values. * Stationary at a level. ** At first difference.

\section{Kao Residual Panel Cointegration Test Results}

The Kao test results are presented in Table 4. The null hypothesis that there is no Cointegration is rejected because ADF statistics and probability is less than $1 \%$. There is causality running from independent to dependent variable.

Table 4: Kao Residual Panel Cointegration Test Results

Kao (Private Consumption (PRVC) as a dependent variable)

Null Hypothesis: There is no Cointegration.

\begin{tabular}{|rll|}
\hline & t-Statistics & Prob. \\
\hline ADF & $-3.276499 * * *$ & 0.0005 \\
\hline$* * *$ Significant at 1\%. &
\end{tabular}




\section{Johansen Fisher Panel Cointegration Test Results}

The Johansen Fisher Panel Cointegration test results are presented in Table 5. Trace Test and Max-Eigen Test indicate three cointegrating equations as the value of Trace Test is greater than Max-Eigen values. So, there are three cointegrating equations, and we reject the null hypothesis that there is no cointegration among the variables.

Table 5: Johansen Fisher Panel Cointegration Test Results

\begin{tabular}{|ccccc|}
\hline $\begin{array}{c}\text { Hypothesized } \\
\text { No. of CE(s) }\end{array}$ & $\begin{array}{c}\text { Fisher Stat. } \\
\text { (From Trace Test) }\end{array}$ & Prob. & $\begin{array}{c}\text { Fisher Stat.* } \\
\text { (From Max-Eigen Test) }\end{array}$ & Prob. \\
\hline None & 89.96 & $0.0000^{*}$ & 56.23 & $0.0000^{* * *}$ \\
At most 1 & 44.41 & $0.0000^{*}$ & 32.44 & $0.0001^{* * *}$ \\
At most 2 & 20.45 & $0.0087^{*}$ & 18.46 & $0.0180^{* * *}$ \\
At most 3 & 13.78 & $0.08^{* * *}$ & 13.70 & $0.0800^{*}$ \\
\hline
\end{tabular}

*** Significant at $1 \%$. at $10 \%$.

\section{Vector Error Correction Model (VECM) Results}

The VECM is applied to measure the speed of adjustment at which the dependent variable returns towards equilibrium due to change in independent variables. The results of the ECM presented in Table 6 indicate that $\mathrm{C}$ (1) error correction term is negative and significant. Thus we can say that there is long-run causality running from independent variables to the dependent variable. The magnitude of ECM is negative and statistically significant that shows that there would be -0.090852 percent speed of adjustment towards longrun equilibrium in the given period and remaining in the next period.

Table 6: Vector Error Correction Model (VECM) Results Estimated with Private Consumption (PRVC) as a target Variable

\begin{tabular}{|ccccc|}
\hline Error Correction & Coefficient & Std. Error & t-Statistic & Prob. \\
\hline D(PRVC) CointEq1 & $\mathbf{- 0 . 0 9 0 8 5 2}$ & $\mathbf{0 . 0 5 1 6 0 0}$ & $\mathbf{- 1 . 7 6 0 6 8 1 * *}$ & $\mathbf{0 . 0 5 0 6}$ \\
D(PRVC(-1)) & 0.402378 & 0.246669 & 1.631250 & 0.1053 \\
D(PRVC(-2)) & -0.574864 & 0.266377 & -2.158081 & 0.0328 \\
D(PRVC(-3)) & 0.608977 & 0.353571 & 1.722359 & 0.0874 \\
D(PRVC(-4)) & 0.247457 & 0.268001 & 0.923342 & 0.3575 \\
D(PD(-1)) & 0.546936 & 0.361152 & 1.514421 & 0.1323 \\
D(PD(-2)) & 0.326491 & 0.321127 & 1.016705 & 0.3112 \\
D(PD(-3)) & -0.309019 & 0.303657 & -1.017658 & 0.3107 \\
D(PD(-4)) & -0.860364 & 0.267190 & -3.220038 & 0.0016 \\
D(LIR(-1)) & -0.264109 & 0.429915 & -0.614327 & 0.5401 \\
D(LIR(-2)) & -0.011658 & 0.593156 & -0.019655 & 0.9843 \\
D(LIR(-3)) & 1.966059 & 0.972816 & 2.020997 & 0.0453 \\
D(LIR(-4)) & 0.384406 & 0.975328 & 0.394130 & 0.6941 \\
D(PUBS(-1)) & 0.046757 & 1.033217 & 0.045254 & 0.9640 \\
D(PUBS(-2)) & 0.089623 & 1.082382 & 0.082802 & 0.9341 \\
D(PUBS(-3)) & -2.790632 & 1.112221 & -2.509063 & 0.0133 \\
D(PUBS(-4)) & -1.073554 & 1.299442 & -0.826166 & 0.4102 \\
D(MS(-1)) & -0.315641 & 0.155048 & -2.035761 & 0.0438 \\
D(MS(-2)) & -0.558515 & 0.145261 & -3.844890 & 0.0002 \\
D(MS(-3)) & 0.550777 & 0.168965 & 3.259709 & 0.0014 \\
D(MS(-4)) & 0.334706 & 0.185732 & 1.802097 & 0.0738 \\
C & 22.10429 & 11.98588 & 1.844194 & 0.0674 \\
\hline
\end{tabular}

** Significant at $5 \%$. 
Cointegrated Equation Long Run Model

$$
\begin{aligned}
& E C T_{i t-1}=1.000000 P R V C_{i t-1}+3.464685 P D_{i t-1}-4.134002 L I R_{i t-1} \\
& -23.14442 P U B S_{i t-1}-1.163366 M_{i t-1}+224.6389
\end{aligned}
$$

\section{Wald Test Results}

The results of the Wald Test are presented in Table 7. The null hypothesis is rejected at a $1 \%$ level of significance means that there is short-run causality running from independent variables to dependent variable.

Table 7: Wald Test Results

\begin{tabular}{|cccc|}
\hline Test Statistic & Value & df & Probability \\
\hline Chi-square & 304.7934 & 9 & $0.0000^{* * *}$ \\
\hline$* * *$ Significant at 1\%. & & &
\end{tabular}

\section{Panel Fully Modified Least Squares (FMOLS) Results}

The results of the Kao test and Johansen Fisher Panel Cointegration test describes in Table 4 and 5 , illustrate that the variables are cointegrated. So, now we have the validity to examine the FMOLS model to check the long-run (LR) relationship among the variables.

Table 8: Panel Fully Modified Least Squares (FMOLS) Results Dependent Variable: Private Consumption (PRVC)

\begin{tabular}{|ccccc|}
\hline Variable & Coefficient & Std. Error & t-Statistic & Prob. \\
\hline PD & 0.628323 & 0.093283 & $6.735660 * * *$ & 0.0000 \\
LIR & -0.925124 & 0.123309 & $-7.502467 * * *$ & 0.0000 \\
PUBS & 1.175468 & 0.556026 & $2.114053 * *$ & 0.0387 \\
MS & 0.205003 & 0.091769 & $2.233907 * *$ & 0.0292 \\
\hline *** Significant at 1\%.** at 5\%.
\end{tabular}

*** Significant at $1 \%$. ** at $5 \%$.

The results of FMOLS presented in Table 8 explain that public debt has a significant relationship with private consumption (PRVC) in the long run. The value of the coefficient of public debt (PD) is 0.6283 shows that one unit increase in public debt leads to an increase in private consumption by 0.62 units. The lending interest rate (LIR) has a negative and significant relationship with private consumption (PRVC). As with one percent increase in lending interest rate decreases private consumption by 0.92 percent. The other variables, i.e. Public Spending (PUBS) and Money Supply (MS), also have a significant positive association with private consumption in the long run.

\section{Conclusion}

The study designs to investigate the impact of some key macroeconomic variables i.e. public debt, public spending, lending interest rate, and money supply on private consumption expenditures in South Asian countries. The level of government debt has a significant negative impact on private consumption. This means that a fiscal expansion that increases the level of government debt will be partly crowded out by a fall in private consumption. The lending interest rate has a significant negative relation with private consumption. Any increase in lending interest rates affects the cost of borrowing money over time, and lower interest rates make borrowing cheaper - allowing people to spend and invest more freely. Increasing interest rates, on the other hand, makes borrowing more costly and can reign in spending in favor of saving. Increased government spending is likely to cause a rise in aggregate demand (AD). This can lead to higher growth in the short-term. Higher government spending will also have an impact on the supply-side of the 
economy-depending on which area of government spending are increased. By increasing the amount of money supply in the economy, the central bank encourages private consumption. Increasing the money supply also decreases the interest rate, which encourages lending and investment. The increase in consumption and investment leads to higher aggregate demand.

\section{References}

Berben, R. P., \& Brosens, T. (2007). The Impact of Government Debt on Private Consumption in OECD Countries. Economics Letters, 94(2), 220-225.

Castro, F., \& de Cos, P. H. (2006). The Economic Effects of Exogenous Fiscal Shocks in Spain: an SVAR approach. ECB Working Paper No.647 (4), 9-31.

Coccia, M. (2017). Asymmetric Paths of Public Debts and of General Government Deficits Across Countries Within and Outside the European Monetary Unification and Economic Policy of Debt Dissolution. The Journal of Economic Asymmetries, 15, 17-31.

Fatas, A., \& Mihov, I. (2001). The Effects of Fiscal Policy on Consumption and Employment: Theory and Evidence. London: Centre for Economic Policy Research, Discussion Paper 2760, 1-36.

Fournier, J. M., \& Fall, F. (2017). Limits to Government Debt Sustainability in OECD Countries. Economic Modelling, 66(C), 30-41.

Im, K. S., Pesaran, M. H., \& Shin, Y. (2003). Testing for Unit Roots in Heterogeneous Panels. Journal of Econometrics, 115(1), 53-74.

Karras, G. (1994). Government Spending and Private Consumption: Some International Evidence. Journal of Money, credit and Banking, 26(1), 9-22.

Keynes, J. M. (1936). The General Theory of Employment, Money and Interest. The collected writings, 7 , 187-221.

Kochin, L. A. (1974). Are Future Taxes Anticipated By Consumers?: Comment. Journal of Money, Credit and Banking, 6(3), 385-394.

Kormendi, R. C. (1983). Government Debt, Government Spending, and Private Sector Behavior. The American Economic Review, 73(5), 994-1010.

Levin, A., Lin, C. F., \& Chu, C. S. J. (2002). Unit Root Tests in Panel Data: Asymptotic and Finite-Sample Properties. Journal of Econometrics, 108(1), 1-24.

Li, S., Wei, L., \& Xu, Z. (2017). Dynamic Asset Allocation and Consumption Under Inflation Inequality: The Impacts of Inflation Experiences and Expectations. Economic Modelling, 61(C), 113-125.

Linnemann, L. (2006). The Effect of Government Spending on Private Consumption: A Puzzle?. Journal of Money, Credit, and Banking, 38(7), 1715-1735.

Musibau, H. O., Mahmood, S., \& Hammed, A. Y. (2017). The Impact of Foreign Capital Inflows, Infrastructure and Role of Institutions on Economic Growth: An Error Correction Model. Academic Journal of Economic Studies, 3(4), 35-49.

Oseni, I. O. (2016). Exchange Rate Volatility and Private Consumption in Sub-Saharan African Countries: A System-GMM Dynamic Panel Analysis. Future Business Journal, 2(2), 103-115.

Peersman, G., \& Pozzi, L.(2004). Determinants of Consumption Smoothing Ghent University, Faculty of Economics and Business Administration. Working paper. (No. 04/231).

Pegkas, P. (2018). The Effect of Government Debt and Other Determinants on Economic Growth: The Greek Experience. Economies, 6(1), 1-19.

Phillips, P. C., \& Perron, P. (1988). Testing for a Unit Root in Time Series Regression. Biometrika, 75(2), 335-346.

Reinhart, C. M., and Rogoff, K. S. (2010). Growth in a Time of Debt (Digest Summary). American Economic Review, 100(2), 573-578.

Shahzad, H., \& Javid, A. Y. (2015). Impact of Debt on Aggregate Investment and Productivity in Developing Asian Countries. Pakistan Institute of Development Economics, 127.

Soon, S. V., Baharumshah, A. Z., \& Mohamad Shariff, N. S. (2017). The Persistence in Real Interest Rates: Does It Solve the Intertemporal Consumption Behavior Puzzle?. Journal of International Financial Markets, Institutions, and Money, 50(C), 36-51. 